ELORE (ISSN 1456-3010), vol. $13-1 / 2006$.

Julkaisija: Suomen Kansantietouden Tutkijain Seura ry. Taitto: Jukka Talve. [http://cc.joensuu.fi/ loristi/1_06/sku1_06.pdf]

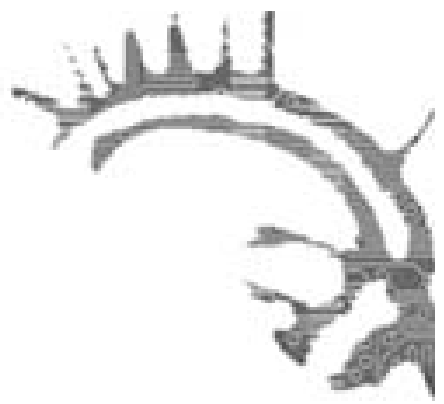

\title{
BetweEn Experience ANd TeXT in ETHNOGRAPHy aNd Oral History
}

\author{
Vieda Skultans
}

There is a dialogue, the exact nature of which is difficult to define. There are seemingly two relationships contained in one - that between informant and the historian, and that between the informant and his own historical consciousness. (Grele 1998, 45.)

How different the process of canonizing a very ordinary life is from what anthropologists or oral historians do. (Feuchtwang 1998, 126.)

A while back Clifford Geertz wrote a chapter on the blurring of genres (Geertz 1993). Nowhere is this more apparent than in the relationship between Ethnography and Oral History: we find ethnographers grappling with memory and representations of the past and oral historians confronting issues to do with experience and the coconstruction of dialogue. In the spirit of this blurring of disciplinary boundaries, I would like to focus on a number of theoretical and methodological issues that beset both Anthropology and Oral History. In the process I hope to identify what they can offer the other and how each can, through dialogue, diminish the other's shortcomings.

Although oral historians are interested in the past and ethnographers by and large in the present, the starting point for both is a compelling engagement with the lives of others. The end point, however, is an academic text that must both encompass the face-to-face encounter and yet address an academic audience in a language with which they are familiar. The questions that haunt us as we write are the ways in which our material can be made relevant to the academic subject and how it can advance theory. These problems are not usually ones that concern our informants. My paper, therefore, seeks to address some of the problems that beset both oral historians and ethnographers as they seek to reconcile a dual allegiance to the experiential encounter and its textual transformation.

Narrative does not require selling as Michael Bell reminds us, least of all to oral historians, but it does require careful handling (Bell 1990,172). With this caution in mind I would like to outline three overlapping theoretical domains, which both 
oral historians and ethnographers must traverse as they seek to move from experience to text. The first domain concerns the nature of the engagement of the researcher in the field situation. The second concerns the engagement of individuals with communal or structural forms of life and the epistemological and ethical implications of such engagement. And the third domain concerns issues of interpretation and translation across different modalities. Each of these domains touches upon the other two domains as I shall show.

\section{ETHNOGRAPHIC ENGAGEMENT IN PLACE OF OBJECTIVITY}

Let me start by considering the role of the researcher. The illusion of the omniscient, objective observer has, of course, lost ground, but the elision of objectivity with truth still persists, and has served to disguise the ambiguities and confusions surrounding the meanings and uses of objectivity. We learn to impose an artificial order on the world and then come to equate that with objectivity.

But as the philosopher Thomas Nagel points out our lives are not lived through the mediation of an external observer: "Life is lived from inside, and issues of significance are significant only if they can be raised from inside." (Nagel 1991, 197.) He argues that there is something irreducible about subjectivity and that it cannot be captured by causal or functional explanations. Nagel illustrates the non-reducibility of consciousness by using the example of the bat.

"Even without the benefit of philosophical reflection anyone who has spent some time in an enclosed space with an excited bat knows what it is to encounter a fundamentally alien form of life." (Nagel 1991, 168.) No amount of understanding of the brain mechanisms of the bat will tell us what it feels like to be a bat. There is an explanatory gap because physical accounts leave out subjectivity. Our own limited human experience precludes us from understanding the experience of the bat. Experience is necessarily subjective and as Nagel points out the very idea of an objective experience is nonsensical.

It is difficult to understand what could be meant by the objective character of an experience, apart from the particular point of view from which the subject apprehends it. After all, what would be left of what it was like to be a bat if one removed the viewpoint of the bat? (Nagel 1991, 173.)

Ignoring the viewpoint of the bat takes us further away rather than closer to understanding its reality. Informants pose equally difficult challenges, though not quite as insuperable as those of bats. The problems are not simply to do with understanding other minds and other cultures, but concern the dialogical nature of understanding and narrative construction. Subjectivity never exists in isolation but always in relationship. As Michael Agar reminds us, "an ethnographer carries more baggage than a tape-recorder and a toothbrush.” (Agar 1996, 91.) That baggage may 


\section{Between Experience and Text in Ethnography and Oral History}

be less tangible but is no less important, than the contents of his or her suitcase. Each of us comes to the ethnographic interview with his or her own personal history and cultural baggage, and the knowledge that we acquire from others is thus necessarily perspectival. This is in no sense a shortcoming, but it does mean that we need to pay attention to our own cultural and biographical backgrounds. This, of course, presents a different scenario from that enacted in the classical fieldwork texts, which are constructed around a duality of observer and observed. The duality is typically represented by describing the moment of arrival in an alien culture. Amanda Coffey is particularly insightful on this subject: "The fieldworker initially and purposely divests him/herself of knowledge and personhood in order to achieve eventual understanding. [..] The heroic displacement of the ethnographer to the margins of the culture in question, and to the social position of an ignoramus, is a preliminary to an even more heroic achievement of knowledge and understanding at the centre of the culture. (Coffey 1999, 20.)

According to this research paradigm distance, estrangement and marginality are prerequisites for staying at the analytic cutting edge. So why are over identification and familiarity seen as a problem as so many handbooks attest? The answer lies, I believe in a negative perception of emotion and the equation of objectivity with a denial of emotion. Whilst there is an acknowledgment that we need rapport and empathy there is a fear of too much rapport. But as Sheryl Kleinman and Martha A. Copp demonstrate denial of emotion is not the same as emotional freedom:

When we ignore our uncomfortable feelings we might think we have achieved the proper emotional state for analytic distance. Feeling distant, indifferent or numb makes us believe that we have freed ourselves from feelings and thus can be objective [..]

But the emotional state we value will inhibit analysis. Moving from anger to distance need not mean that our head now controls our heart. Distance can indicate that we are numb to our feelings. [..] Numbness may protect the individual from experiencing particular feelings but numbness itself is an overpowering feeling state. It involves a reduction not an enhancement, of our cognitive faculties. (Kleinman \& Copp 1993, 33.)

What matters more than the amount and intensity of our feelings is what we do with them and how much self awareness they engender (Kleinman \& Copp 1993, 45). This perspective provides us with a rejoinder to the standard criticism of reflexive ethnography as self absorbed and narcissistic. For as Babcock argues the problem with Narcissus was not that he was too taken up with his own image, but that he was not taken up enough. In other words, he was not critical enough (Babcock 1980, 2).

Reflexivity, according to Maurice Merleau-Ponty, concerns "knowing how we are grafted onto the universal by that which is most our own" (Merleau-Ponty 1964, 52). From the phenomenological perspective no hard and fast line can be drawn between subjectivity and the objective world. The external world comes into being through the experiential self. 
These problems of engagement with fieldwork are not of course confined to the discipline of Anthropology. They confront oral historians also as Ronald J. Grele has noted:

Oral history, almost alone among the various practices of historiography is heavily dependent upon fieldwork, which means that not only can we come back again and again to our sources and ask them to tell us more, but we can also explore the varieties of historical visions in far greater detail amid radically changing historical conditions. (Grele 1998, 47-48.)

Because of this dependence on fieldwork oral historians are faced with the same problems regarding self and emotion and have to perform a fine balancing act between identification and indifference, between sameness and indifference. Alessandro Portelli is well aware of this when he writes of the fear that: "Once the floodgates of orality are opened, writing (and rationality with it) will be swept out." (Portelli 1998, 64.) What I am suggesting is that emotion has been feared because it threatens the self other divide but that its suppression created an ethnography of cardboard figures, or "outlines waiting to be filled" to use Clifford Geertz's apt description.

If the anthropologist Edmund Leach was able to claim that the "individual's feelings are inaccessible to the anthropological investigator (or to any other kind of investigator)", it was because his own feelings were inaccessible to him (Leach 1984, 360). The immediacy of the ethnographic counter and the compelling nature of our informants' accounts require us to be aware of our emotions and their potential impact and shaping of the ethnographic data.

\section{DoEs BEING “A HALFIE” HeLP?}

One way of trying to resolve the problem of sameness and difference and of engagement and distance is through the notion of "a halfie" introduced by the American Egyptian anthropologist Lila Abu-Lughod (1991). Born of Egyptian parents but educated in North America she considers herself to belong to two cultures. There are increasing numbers of such "halfies" among ethnographers and, of course, they predominate among oral historians, who are less likely to study exotic distant peoples' and more likely to carry out their studies closer to home. Dorinne Kondo (1990), an American Japanese anthropologist did fieldwork in Japan, Barbara Myerhoff (1978), an American- Jewish anthropologist worked in a Jewish old people's centre, and Ruth Behar (1996) returned to her Hispanic roots through her fieldwork. These "halfies" write ethnographies in "a different voice" to transpose Carol Gilligan's (1982) phrase, where room is made for the creative differences and particularities of individuals and their lives. Myerhoff writes of her fieldwork experience thus: "Working with one's own society, and more specifically, those of one's own ethnic and familial heritage, is perilous, and much more difficult. Yet it has a certain validity and value not available 


\section{Between Experience and Text in Ethnography and Oral History}

in other circumstances. Identifying with the 'Other' - Indians, Chicanos, if one is Anglo, blacks if one is white, males if one is female - is an act of imagination, a means for discovering what one is not and never will be. Identifying with what one is now and will be someday is quite a different process." (Myerhoff 1978, 18.) And in my case, as an emigree Latvian, identifying with what might have been is an equally unsettling and, indeed, uncanny experience. Geertz, in his introduction to Myerhoff's book refers to her as thrice-born. The first birth being into one's natal culture, the second birth being the ethnographic encounter with the exotic, and the third birth being a return to one's own culture with new eyes which make the familiar exotic.

One brand of "halfie" ethnography relates to illness and here "halfies" have produced some spectacular work. Susan Sontag (1983) has written that we are all citizens of two kingdoms: the kingdom of the well and the kingdom of the ill. Although we prefer to travel with the well passport, each one of us will be forced at some stage to use our other passports. Arthur Frank and Robert Murphy have demonstrated the experiential purchase that such dual citizenship confers (Frank 1995; 2001; Murphy 1990).

Technically "halfie" refers to ethnographers whose roots are in the society they are researching. But as Michael Agar points out we are all "halfies" nowadays. "Ethnographers and others swim in the same interconnected global soup." (Agar 1996, 21.) But at a more fundamental level we are all halfies now because the myth of the other has been shown to be just that, it has been exposed. The power relationship between researcher and informant is no longer set in stone. And yet the researcher's relationship to key informant is full of emotional and ethical dilemmas:

The feminist sociologist Judith Stacey reveals her ambivalent position over an informant's death providing her, as it does, with rich fieldwork opportunities. Stacey has argued that it is precisely the closeness engendered by feminist ethnographic practice that is responsible for "inauthenticity, dissimilitude, and potential, perhaps inevitable, betrayal". (Stacey 1991,113-114.) Emotional connectedness and empathic understanding should not disguise the fact that the ethnographer and informant have different motivations in participating in the research. Miriam Glucksman describes this as: "the different and unequal relation to knowledge of the researched and researcher." (Glucksman 1994, 159.) Re-naming informants respondents or participants does not empower them in any real sense. It may simply be a way of "attempting to establish an egalitarianism in the research situation as a substitute for establishing it in the "real world"' (Glucksman 1994, 151). And as Smith argues obtaining approval for sociological texts is often not real approval but a form of capitulation (Frank 2001, 356).

I suppose to be honest I would have to recognize that one's motives are always a varying mixture of the personal and the altruistic and that it is their combination that matters particularly as it affects the practice of ethnography at particular moments. If at the most painful culmination of a patient's story my concern is for my tape-recorder rather than the patient then there is clearly something wrong with the combination. These are the dilemmas of witnessing that Ruth Behar attempts to identify. She writes: "In the midst of a massacre, in the face of torture, in the eye 
of a hurricane, in the aftermath of an earthquake, or even, say, when horror looms apparently more gently, in memories that won't recede and so come pouring forth in the late-night quiet of a kitchen, as a storyteller opens her heart to a story listener, recounting hurts that cut deep and raw into the gullies of the self, do you, the observer, stay behind the lens of the camera, switch on the tape recorder, keep pen in hand? Are there limits - of respect, piety, pathos - that should not be crossed, even to leave a record." (Behar 1996, 2.) Her way of resolving such dilemmas is not to separate the ethnographic voice from the personal and emotional voice, but to write personally and vulnerably (Behar 1996, 17).

\section{SHOULD WE "THINK WITH STORIES"?}

And yet despite the ambiguities of the ethnographic encounter there is an emotional immediacy and power that all researchers will be familiar with. Arthur Frank has identified this power in his distinction between "thinking with stories" rather than "thinking about stories" (Frank 1995; 2001). So what is the difference? As I understand this distinction "thinking with" stories makes room for a greater degree of empathy with the storyteller which in turn makes demands upon our moral imagination.

"Thinking with" stories is an experiential and transformative process. When confronted with the pain and suffering of others, stories exert a moral obligation on the listener not to turn away but to acknowledge and share (Morris 2002,197). Much of the literature on "thinking with stories" derives from the work of Levinas and his concept of face.

And this kind of thinking is transformative. John Shotter is very good on this transformative process: "What the voices of others can do for us that we cannot do for ourselves, is that their otherness which enters into us makes us other. They can arouse a dialogically structured response in us, they can create possibilities of change within us that we cannot create within ourselves alone." (Shotter 2004, 8.) Shotter refers to this kind of understanding as relational rather than representational. Our informants expect relational understanding rather not duplication in our responses. This kind of relational response is difficult to pin down but I suspect it determines the difference between research that yields thick and thin descriptions, or between rich and skeletal narratives.

Thus stories exert a claim or a call upon our moral imagination and compel us to listen. Adriana Cavarero writes of the way "who-questions" often collapse into "what-questions" (Cavarero 2000). If we ask of someone who they are, it is easier to reply by describing what they are: a teacher, a UK citizen, a white woman etc. But "who-questions" can only be answered by giving a narrative account, a story of past experience and how they came to be the person that they are. A life story invites us to think with stories. By contrast if we think about stories we do not engage the moral imagination in the same way. A good example of thinking about stories is William Labov's (1977) classic study of language use among inner city youths. Labov's intention 


\section{Between Experience and Text in Ethnography and Oral History}

was to rehabilitate colloquial language, but in the process of analysis he succeeds in dismantling any power it might have had. In thinking about stories, in dismembering them he succeeds in reducing them.

There are many other examples of thinking about stories. What they have in common is a translation from one modality to another. We could describe this as a translation from an experiential narrative to theoretical discourse. Theory involves removing the narrative account which constructs meaning in its own terms, to another context where meaning is constructed in extra-local terms. Usually thinking about stories involves seeing the story as an example of a particular kind of mentality. For example, primitive mentality, or psychopathological mentality. Here language is seen as a symptom rather than sign. Even Labov's work which is about linguistic creativity sees inner city discourse as an exemplar of more general linguistic rules.

Underpinning this distinction of thinking with versus thinking about stories is an earlier dualism over the construction of time that Johannes Fabian identified as lying at the heart of the anthropological enterprise of constructing the other and that he describes as the denial of coevalness. He defines coevalness as "A persistent and systematic tendency to place the referent(s) of anthropology in a Time other than the present of the producer of anthropological discourse" (Fabian 1983, 31). And yet this denial is premised on a contradiction. For fieldwork to be carried out "intersubjectivity" must be achieved. Anthropologist and informant must share the same dialogic experiences in time. "Coevalness has to be created. Communication is, ultimately about creating shared time." "Either he submits to the condition of coevalness and produces ethnographic knowledge, or he deludes himself into temporal distance and misses the object of his search." (Fabian 1983, 31-32.)

What Fabian has identified here in his own convoluted prose is the experiential and dialogic context in which ethnographic information is gained and the decontextualized, timeless generalizations into which such intersubjective experiences are translated. That intersubjectivity is attacked in different ways by anthropologists and oral historians as Dudley demonstrates. "Whereas ethnography erases the textproducing activities of the informant, oral history erases the text-producing activities of the interviewer" (Dudley 1998, 163). However, whatever the site of erasure the end result is the same: "A bit of the real, then, is always sacrificed to gain the appearance of the true." (Dudley 1998, 165.) Portelli makes the same point when he writes: "When the researcher's voice is cut out, the narrator's voice is distorted.” (Portelli 1998, 71.)

\section{ENGAGEMENT WITH THE SOCIAL}

So far I have not stepped beyond my first domain of researcher engagement. It has taken so much time because recognizing one's own and the other's subjectivity is crucial to identifying the important issues in the other two domains. Let me now move on to the second domain: the engagement of individuals with communal forms of life. We have come a long way since an anthropologist was able to describe life 
stories as having: "disconcerting tendency to say both more and less than the anthropologist wishes to hear." Michael Young $(1983,479)$ attributes the limitations of this genre to "the inability of even the most intelligent and articulate narrator to reveal more than the surface structures of his or her culture".

This view is based on a polarization between an essentialized self and culture, between informant and researcher and between local knowledge and theoretical knowledge. However, narratives can be profoundly "knowing" of the fault lines of society in a way that earlier anthropologists hardly perceived. Gareth Williams (2004), for example, in his work with people coping with chronic illness, demonstrates how lay narratives can incorporate quite sophisticated epidemiological understandings and social critiques. My own work in Latvia has made connections between illness narratives and quite radical critiques of soviet oppression.

\section{Latvian Case Studies}

In Soviet Latvia narratives of the body and the self and shared narratives of history collapse into each other. This identification between self and history has disappeared with the new individualist ethos of capitalism. But for the older generation, certain historical events such as deportations, collectivization and the expropriation of private property have had a profound influence on both medical and lay thinking about the body and illness. Emmanuel Le Roy Ladurie writes of a creative event - the evenement matrice - which destroys traditional structures and brings about new structures (Ladurie1979,130). The Soviet occupation of the Baltic states and its aftermath could with a certain irony be termed such creative events which called for a radical restructuring of medical thinking about the body.

Latvian narrators define their individual illness histories in relationship to the social world. In particular, autobiographies of illness are shaped by major turning points in Soviet history with their inevitable social and individual consequences. One of my informants, Mara redefines her own and her family's health in relation to the events which followed the Soviet occupation. Illness is the mode in which Latvians articulate their relationship to history and in doing so transfer it from the private to the public domain. The experience and narrativization of illness is deeply politicized and collectivized. The generous provision of medical diagnoses as well as medical care has to be seen in the light of a highly politicized and historicized lay perspective on illness.

Mara sets her illness history in the context of forced collectivization. She comes from the parish of Drusti in N.W. Vidzeme. Her farm was located on the outskirts of the parish remote from others and surrounded by forest. The policy of driving people out of their farms into centralized apartment blocks involved fierce measures such as blocking up wells and digging up roadways. Here Mara relates her health difficulties to this process of centralization: 


\section{Between Experience and Text in Ethnography and Oral History}

Well, I began to be ill when I was about twenty. When the children started going to school at that time I was ill with asthma. I had asthma. If I worked harder or washed clothes or got hot then I would suffocate terribly. Well and we lived far from the road so I couldn't call the doctor just at that time. So I would wait a little until it was over and then they would think I was putting it on or something... We didn't have electricity there, we weren't allowed to install it. We were all driven into the villages. Then I started washing the clothes in a machine and then I didn't get hot... and then it started getting better... Of course my heart had been affected and I got tired easily. So I can't say that my health has been good. And with regard to my nerves well [..] it's clear that my nerves suffered along with these events. They suffer from all of that.

This case study illustrates the "thickness" of medical narratives: Mara's medical autobiography reaches out to encompass events and structures in the political arena. Her medical history bears the signature of a public history. For this reason medical encounters frequently turn into social dramas of the kind described by Victor Turner (1974): concealed conflicts, opposing interpretations of the past and present emerge in the course of the medical encounter. Patients challenge existing structures in the light of their individual experience. The following account of the doctor's visit to Mara's farmstead during her second pregnancy constitutes such a social drama in which the conflicting needs of childbirth and the state's demands for timber are pitted against each other. In a society short of labour power due to war deaths and deportations the role of the doctor in granting access to the sick role was particularly fraught and accusations of malingering were common. The folk wisdom on this issue is summed up in an anecdote which Mara recounted to me.

Everyone, men and women, had to work. The women even if they had small children. One was only let off work with a doctor's certificate. But the doctors were hesitant: everyone feared deportation. Even the sick. couldn't get a certificate and often they died working. In hospitals they used the word "malingerer" [Latvian: 'simulants'] or rogue. Let me give you an anecdote. In the morning the doctor asks the duty nurse "What's new?" She answers, "Nothing much, only the malingerer has died!"

However, this challenge is not issued on a private or ad hoc basis. Rather the experience of illness and its emotional reverberations provide a principle mechanism for transforming private memory into public or social memory. In the course if this transformation the body and its historical experience are invested with a rationality and wisdom of their own. This cultural configuration reverses certain other powerful and common stereotypes such as, "a deep-seated cultural stereotype [..] which pictures the body as an anarch, a lord of misrule, emblematic of excess in food, drink, sex, violence - the embodiment of the principle which Freud later intellectualized as the 'id"'. (Porter 1991, 217.)

This kind of work with life histories can challenge their earlier lowly status, one consequence of a scientism which dismissed the particular. In Anthony Cohen's words there is: "an anthropology to which people - individuals - are almost purely 
incidental" (Cohen 1996, 29). But the ascendance of the narrative and life-history approach has compelled us to recognize our informants as theorists and moral agents on a par with ourselves. Renato Rosaldo summarizes this as follows: "Indeed, one strength of analytical narratives is that they can do so many jobs at once. Unlike more single-minded hypothetico-deductive propositions, stories can simultaneously encompass a number of distinct plot lines and range yet more widely by describing the lay of the land, taking overviews of the situation and providing key background information (Rosaldo 1980, 91). This recognition is important for the entire social science enterprise. For oral historians, the situation has been somewhat different since its origins as an off-shoot of archival history has placed "an emphasis on truth and validity rather than meaning" (Summerfield 2000, 92). But equally this has downplayed the importance of subjectivity, seeing oral history as an addition to archival truth. However, the influence of narrative theory, with its emphasis on form as well as content, has given rise to a different and enlarged kind of oral history. Portelli summarizes this well: "Oral sources tell us not just what people did, but what they wanted to do, what they believed they were doing, and what they now think they did." (Portelli 1998, 67.) The influence of a particular kind of interpretive anthropology is evident here which sees ethnographic understanding as "more like grasping a proverb, catching an allusion, seeing a joke or [..] reading a poem" (Geertz 1993, 70). Geertz's words remind us that much knowledge may be implicit or inarticulate.

\section{ENGAGEMENT WITH THE TEXT}

So what are the epistemological and ethical implications of recognizing the engagement of persons with social structure? Although, as mentioned earlier, the motivations of researcher and informant are different, both are theorists trying to make sense of the past. Perhaps, making sense or seeing a pattern in the particularities and twists and turns of a life constitute one of the greatest challenges for theoretical understanding. The ethical consequence of this is that we treat our informants' worldview with the same respect we accord our own.

Let me now move onto my final domain and the problem of translation, which cuts across all the issues discussed so far. Translation is involved when we move from one modality to another, be that from culture to culture, from person to person, from orality to textuality, from experience to narrative and from local embodied knowledge to generalization. Thus translation involves the personal engagement of the researcher. George Steiner writes: "Thus a human being performs an act of translation, in the full sense of the word, when performing a speech-message from any other human being. Time, distance, disparities in outlook or assumed reference make this act more or less difficult." (Steiner 1992, 48.) But translation rests upon an assumption of a more basic proficiency. Hans G. Gadamer reminds us of the radical difference between learning a first language and learning a second language. In learning a first language our very world is brought into being. But learning a new language 


\section{Between Experience and Text in Ethnography and Oral History}

"involves acquiring a new standpoint in regard to one's previous worldview." (Gadamer 1989, 441.) It also requires translation and interpretation in a way that learning a first language does not. But there is no mediating third language in this translation unless as George Gellner suggests "Reality itself could be this kind of mediator and third language" (Gellner 1970, 25).

But as we know, reality is a fuzzy and slippery concept and we are better off here with the idea of shared experience, in our case the ethnographic interview. And here I want to introduce the idea of unequal languages and translation as a political act (Alvarez \& Vidal, 1996). Talal Asad $(1986,157)$ has pointed out how translator's have a greater reverence for their own language than the language of the other. The task of the translator is to move between, their first language and the foreign language or culture and between experiential and theoretical understanding without seeking to impose one upon the other. Here we return to the importance of recognizing our informants as theorists. The ethnographer must draw new meanings from quasi incommensurable worlds. There are no all-encompassing dictionaries in which to check whether our translations are correct. But if successful the creative act of translation will give "language life beyond the moment and place of immediate utterance" (Steiner 1992, 28).

Let me spell out what I mean by incommensuralibity across modalities and the kind of calls upon creativity that these require. The incommensurability of cultures is familiar to us since the work of Wittgenstein and his discussions of forms of life. For this reason translation, as Asad points out, has been the key concern of the structural-functionalist school of Anthropology. The incommensurability of personal experience is the focus of the problem of other minds. Orality and textuality have been discussed in terms of the subservience of speech to text but I wish to discuss their incommensurability and problems of transcription by focusing on the nature of eloquence in speech and writing. Literal transcriptions are often unreadable. A faithful translation from spoken to written word often loses the power and eloquence of the spoken narrative. In other words, eloquence in speech is not the same as eloquence in writing. Hence, there is an urge to tidy up speech in transcription in order not to render an eloquent speaker inarticulate. Again an act of creative interpretation is called for. So successful transcription "does not mark a technical achievement facilitated by a shared code of practice of transcribing but rather celebrates the beginnings of a dialogue made by giving narrative shape to an individual's life project" (Skultans 2000, 9). Elliot Mishler refers to this as "the essential indeterminacy and ambiguity of the relationship between language and meaning" (Mishler 1991, 235). And finally we have the movement from the embodied experiential ethnographic setting to stored verbal knowledge. There is an implicit contract between researchers and informants that we will know how to negotiate this modality and give a different shape to the relived experiences. This is particularly so with painful experiences and memories. If, as Michael Bell points out, there is no contract in life, the contract in narrative is all the more important (Bell 1999, 175). What characterises all these moves across modalities is the absence of one-to-one correspondences and the need for imaginative recreation and transposition. 


\section{Vieda Skultans}

\section{Conclusions}

Insofar as ethnography and oral history are hermeneutic disciplines, interpretation is fundamental to all aspects of their work and ranges across different pairs of modality. Our two disciplines call for a dialogic engagement with the other across the full range of human subjectivity, from embodied experience to cultural abstraction. For anthropologists this has involved moving away from Pascal's position summed up in the dictum. "We have truth, they have tradition". More recently anthropologists have argued against the neglect of the self in ethnographic work.

A more recent movement in Anthropology has challenged this position. For example, Cohen has argued extensively against the neglect of the self by anthropologists: "Anthropologists did not attribute any importance to the problem of what these structures actually meant to those who populated them. In this kind of theoretical scheme, people, individuals, were important only as structures in themselves, or as related to structure in some identifiable way." By contrast Cohen argues that individuals construct their relationship to society on their own terms. (Cohen 1994, 14, 79.)

The position that Cohen is challenging is exemplified in the work of Edmund Leach among others. He wrote: "The stories that I am interested in are repetitive and in some degree "traditional"; I am not concerned with one-off inventions of children struggling to gain control of syntax or learning to imitate models that meet with the approval of their elders." (Leach 1984, 361.) Leach, with his inimitable combination of radicalism and upper class authoritativeness, would not have seen himself as a mouthpiece for any social group. He would I feel sure have wanted his contribution to Anthropology to be seen as unique rather than a replica of anyone else. And yet in doing ethnographic fieldwork he was denying that importance to others.

Oral historians on the other hand have moved from a recognition of the particularity of their subjects to a recognition of their informants as creators of cultural meaning. The movement can be characterized by a variation of Rosaldo's account of fieldwork among the Ilongots. He came looking for culture but found history. "And through their history I discovered culture in a renewed sense" (1980, 90). Conversely it could be said of oral historians that they were looking for history and found culture and through culture rediscovered a renewed sense of history.

\section{REFERENCES}

ABU-LUGHOD, LILA 1991: Writing against Culture. - Fox, Richard (ed.), Recapturing Anthropology. Santa Fe, New Mexico: School of American Research Press. AGAR, MICHAEL 1996 (ed.): The Professional Stranger. An Informal Introduction to Ethnography. San Diego: Academic Press. 


\section{Between Experience and Text in Ethnography and Oral History}

ALVAREZ, ROMAN \& VIDAL, M. CARMEN-AFRICA 1996 (eds.): Translation, Power, Subversion. Clevedon, Philadelphia: Multi-lingual Matters.

ASAD, TALAL 1986: The Concept of Cultural Translation. - Clifford, James E. \& Marcus, George E. (eds.), Writing Culture. The Poetics and Politics of Ethnography. Berkeley: University of California Press.

BABCOCK, BARBARA 1980: Reflexivity: Definitions and Discriminations. - Semiotica 30(1-2): 1-14.

BEHAR, RUTH 1996: The Vulnerable Observer. Anthropology That Breaks Your Heart. Boston: Beacon Press.

BELL, MICHAEL 1990: How Primordial is Narrative? - Nash, Christopher (ed.), Narrative in Culture. The Uses of Storytelling in the Sciences, Philosophy and Literature. New York: Routledge.

CAVARERO, ADRIANA 2000: Relating Narratives: Storytelling and Selfhood. London: Routledge.

COFFEY, AMANDA 1999: The Ethnographic Self: Fieldwork and the Representation of Identity. London: Sage.

COHEN, ANTHONY 1994: Self Consciousness. An Alternative Anthropology of Identity. London: Routledge.

COHEN, ANTHONY \& RAPPORT, NIGEL 1996 (eds.): Questions of Consciousness. London: Routledge.

DI LEONARDO, MICAELA 1987: Oral History as Ethnographic Encounter. - Oral History Review 15: 1-20.

DUDLEY, KATHRYN MARIE 1998: In the Archive, in the Field. What Kind of Document is an "Oral History"? - Chamberlain, Mary \& Thompson, Paul (eds.), Narrative and Genre. London: Routledge.

FABIAN, JOHANNES 1983: Time and the Other. How Anthropology Makes its Object. New York: Columbia University Press.

FEUCHTWANG, STEPHAN 1998: Distant Homes, Our Genre. Recognizing Chinese Lives as an Anthropologist. - Chamberlain, Mary \& Thompson, Paul (eds.), Narrative and Genre. London: Routledge.

FRANK, ARTHUR 1995: The Wounded Storyteller: Body, Illness and Ethics. Chicago: University of Chicago Press.

- 2001: Can We Research Suffering? - Qualitative Health Research 11(3): 353-362.

GADAMER, HANS G 1989: Truth and Method. London: Sheen and Ward.

GEERTZ, CLIFFORD 1993: Blurred Genres. The Refiguration of Social Thought in Local Knowledge. London: Fontana.

GELLNER, ERNEST 1970: Concepts and Society. - Wilson, Bryan (ed.), Rationality. Oxford: Basil Blackwell.

GILLIGAN, CAROL 1982: In a Different Voice: Psychological Theory and Women's Development. Cambridge, Mass.: Harvard University Press

GLUCKSMANN, MIRIAM 1994: The Work of Knowledge and the Knowledge of Women's Work. - Maynard, Mary \& Purvis, June (eds.), Researching Women's Lives from a Feminist Perspective. London: Taylor and Francis. 
GRELE, RONALD J. 1998: Movement Without Aim: Methodological and Theoretical Problems in Oral History. - Perks, Robert \& Thomson, Alistair (eds.), The Oral History Reader. London: Routledge.

KLEINMAN, SHERYL \& COPP, MARTHA A. 1993: Emotions and Fieldwork. Newbury Park: Sage.

KONDO, DORINNE K. 1990: Crafting Selves: Power Gender and Discourses of Identity in a Japanese Workplace. Chicago: Chicago University Press.

LABOV, WILLIAM 1977: Language and the Inner City. Oxford: Blackwell.

LADURIE, EMMANUEL LE ROY 1979: The Territory of the Historian. Hassocks: Harvester.

LEACH, EDMUND 1984: Further Thoughts on the Realm of Folly. - Bruner, Edward M. (ed.), Text, Play and Story. The Construction and Reconstruction of Self and Society. Prospect Heights, Illinois: Waveland Press

MERLEAU-PONTY, MAURICE 1964: Signs. Evanston: Northwestern University Press.

MISHLER, ELLIOT G. 1991: Representing Discourse: The Rhetoric of Transcription. - Journal of Narrative and Life History 1: 255-280.

MORRIS, DAVID B. 2002: Narrative, Ethics and Pain: Thinking with Stories - Charon, Rita \& Montello Martha (eds.), Stories Matter The Role of Narrative in Medical Ethics. London: Routledge.

MURPHY, ROBERT 1990: The Body Silent. New York: Norton.

MYERHOFF, BARBARA 1978: Number Our Days. New York: Touchstone.

NAGEL, THOMAS 1991: Mortal Questions . Cambridge: Cambridge University Press. PORTELLI, ALESSANDRO 1998: What Makes Oral History Different. - Perks, Robert \& Thomson, Alistair (eds.), The Oral History Reader. London: Routledge.

ROSALDO, RENATO 1980: Doing Oral History. - Social Analysis 4: 89-99.

RUBY, JAY 1982 (ed.): A Crack in the Mirror Reflexive Perspectives in Anthropology Pennsylvania: University of Pennsylvania Press.

SHOTTER, JOHN 2004: Expressing and Legitimating Actionable Knowledge from Withi. - Unpublished paper. 21.08. 2004. New Orleans, Academy of Management Conference.

SKULTANS, VIEDA 2000: Introduction. - Anthropology and Medicine [Special issue on Narrative, Illness and the Body] 7(1): 1-9.

SONTAG, SUSAN 1983: Illness as Metaphor. Harmondsworth: Penguin

STACEY, JUDITH 1991: Can There Be a Feminist Ethnography? - Gluck, Sherna Berger \& Patai, Daphne (eds.), Women's Words. The Feminist Practice of Oral History. London: Routledge.

STEINER, GEORGE 1992: After Babel Aspects of Language and Translation. London: Oxford University Press.

SUMMERFIELD, PENNY 2000: "Dis/composing the Subject: Intersubjectivities in Oral History”. - Coslett, Tess \& Lury, Celia \& Summerfield, Penny (eds.), Feminism and Autobiography: Texts, Theories and Methods. London: Routledge.

TURNER, VICTOR 1974: Dramas, Fields and Metaphors: Symbolic Action in Human Society. New York: Cornell University Press. 
WILLIAMS, GARETH AUGUST 2004 [in press]: Narratives of Health Inequality: Interpreting the Determinants of Health. - Hurwitz, Brian \& Greenhalgh, Trisha \& Skultans, Vieda (eds.), Narrative Research in Health and Illness. London: British Medical Journal Books.

YOUNG, MICHAEL 1983: Our Name Is Women: We Are Brought with Limesticks And Limepots: An Analysis of the Autobiographical Narrative of a Kalauna Woman. - Man. Journal of the Royal Anthropological Institute 18 (3): 478-501.

BA Hons. (London), PhD (Wales) Vieda Skultans is a professor at the Department Sociology, University of Bristol, United Kingdom. 